\title{
Evaluating the effectiveness of road mitigation measures
}

\author{
Edgar A. van der Grift • Rodney van der Ree • Lenore Fahrig • \\ Scott Findlay • Jeff Houlahan • Jochen A. G. Jaeger • Nina Klar • \\ L. Francisco Madriñan • Leif Olson
}

Received: 30 July 2012/Accepted: 6 December 2012/Published online: 19 December 2012

(C) The Author(s) 2012. This article is published with open access at Springerlink.com

\begin{abstract}
The last 20 years have seen a dramatic increase in efforts to mitigate the negative effects of roads and traffic on wildlife, including fencing to prevent wildlifevehicle collisions and wildlife crossing structures to facilitate landscape connectivity. While not necessarily explicitly articulated, the fundamental drivers behind road mitigation are human safety, animal welfare, and/or wildlife conservation. Concomitant with the increased effort to mitigate has been a focus on evaluating road mitigation. So far, research has mainly focussed on assessing the use of wildlife crossing structures, demonstrating that a broad range of species use them. However, this research has done little to address the question of the effectiveness of crossing structures, because use of a wildlife crossing structure does not necessarily equate to its effectiveness. The paucity of studies directly
\end{abstract}

E. A. van der Grift $(\bowtie)$

Alterra, Wageningen University and Research Centre, P.O. Box 47, 6700 AA Wageningen, The Netherlands

e-mail: edgar.vandergrift@wur.nl

R. van der Ree

Australian Research Centre for Urban Ecology, Royal Botanic Gardens Melbourne, School of Botany, University of Melbourne, Melbourne, VIC 3010, Australia

e-mail: rvdr@unimelb.edu.au

L. Fahrig

Geomatics and Landscape Ecology Laboratory, Department of Biology, Carleton University, 1125

Colonel By Drive, Ottawa, ON K1S 5B6, Canada

e-mail: lenore_fahrig@carleton.ca

S. Findlay

Institute of the Environment \& Ottawa-Carleton Institute of Biology, 555 King Edward, Ottawa, ON K1N 6N5, Canada

e-mail: findlay@uottawa.ca

J. Houlahan

Department of Biology, University of New Brunswick at Saint John, Saint John, 5050, New Brunswick E2L 4L5, Canada

e-mail: jeffhoul@unbsj.ca 
examining the effectiveness of crossing structures is exacerbated by the fact that such studies are often poorly designed, which limits the level of inference that can be made. Without well performed evaluations of the effectiveness of road mitigation measures, we may endanger the viability of wildlife populations and inefficiently use financial resources by installing structures that are not as effective as we think they are. In this paper we outline the essential elements of a good experimental design for such assessments and prioritize the parameters to be measured. The framework we propose will facilitate collaboration between road agencies and scientists to undertake research programs that fully evaluate effectiveness of road mitigation measures. We discuss the added value of road mitigation evaluations for policy makers and transportation agencies and provide recommendations on how to incorporate such evaluations in road planning practices.

Keywords Wildlife - Population viability - Road mitigation - Crossing structures · Monitoring · Effectiveness · Guidelines

\title{
Introduction
}

In recent decades, transportation agencies have become increasingly aware of the effects of roads, railroads and other linear infrastructure on wildlife (Forman and Alexander 1998; Trombulak and Frissell 2000; Coffin 2007). Roads and traffic may increase mortality of wildlife due to wildlife-vehicle collisions, act as barriers to animal movement and migration, and affect both the amount and quality of wildlife habitat (Spellerberg 2002; Forman et al. 2003). Consequently, roads and road networks potentially jeopardize the long-term persistence of wildlife populations, communities and ecosystems (van der Grift et al. 2003; Jaeger and Fahrig 2004; Fahrig and Rytwinski 2009; van der Ree et al. 2009; Benítez-López et al. 2010; Borda-de-Agua et al. 2010; Kociolek et al. 2011).

Concern for the impacts of roads on wildlife has resulted in efforts to mitigate these effects (Forman et al. 2003). Mitigation measures include wildlife warning signs, measures to reduce traffic volume and/or speed, animal detection systems, wildlife reflectors, wildlife repellents, modified road designs/viaducts/bridges, changes in road-verge

\author{
J. A. G. Jaeger · L. F. Madriñan \\ Department of Geography, Planning and Environment, Concordia University Montreal, 1455 de \\ Maisonneuve Blvd. W Suite H1255, Montreal, QC H3G 1M8, Canada \\ e-mail: jochen.jaeger@concordia.ca \\ L. F. Madriñan \\ e-mail: madvald@hotmail.com \\ N. Klar \\ Department of Ecological Modelling, UFZ Centre for Environmental Research Leipzig-Halle, \\ Permoserstr. 15, 04318 Leipzig, Germany \\ e-mail: ninaklar@gmx.de
}

\section{N. Klar}

Department of Human Biology and Anthropology, Freie Universität Berlin, Albrecht-Thaer-Weg 6, 14195 Berlin, Germany

L. Olson

O2 Planning and Design, 510255 17th Ave SW, Calagary, AB T2S 2T8, Canada

e-mail: leif.olson@gmail.com 
management, wildlife fences, wildlife crosswalks, and wildlife crossing structures (Iuell et al. 2003; Clevenger and Ford 2010; Huijser and McGowen 2010). Wildlife crossing structures, combined with wildlife fences that prevent animals from accessing roads and that guide animals towards the crossing structures, are gaining attention by transportation agencies because they provide safe wildlife passages without affecting traffic flow. Hence they improve human safety, reduce property damage and decrease the risk of local population extinction due to wildlife mortality and/or population isolation. Wildlife crossing structures include both underpasses (e.g., amphibian tunnel, badger pipe, ledges in culvert) and overpasses (e.g., land bridge, rope bridge, glider pole).

Road mitigation measures are common in some parts of the world (Trocmé et al. 2003). Mitigation measures are most likely to be considered when new roads, road extensions or road upgrades are proposed (Evink 2002). Occasionally, existing roads may be retrofitted (van der Grift 2005). Investments in road mitigation measures can be substantial. For example, in the Netherlands 70 million euros (10\% of road project budget) were spent on the construction of 85 wildlife crossing structures, $80 \mathrm{~km}$ of wildlife fences and 185 ha of habitat restoration, to counteract the expected impacts of a $42-\mathrm{km}$ highway extension (Kusiak and Hamerslag 2003). The Netherlands has also allocated about 410 million euros to a national defragmentation program that aims to retrofit crossing structures to existing highways, railroads and waterways (van der Grift 2005). In the USA, 94 million dollars were spent by the federal government on road mitigation measures between 1992 and 2008 (National Transportation Enhancements Clearinghouse 2009) and currently 10 million dollars $-7.5 \%$ of the road project budget - is invested in road mitigation at U.S. Highway 93 at the Flathead Indian Reservation, Montana, USA, including 41 wildlife and/or fish crossing structures (Becker and Basting 2010; P.B. Basting, personal communication).

But to what extent are such measures effective? Most research has focussed on assessing the use of wildlife crossing structures (e.g., Hunt et al. 1987; Foster and Humphrey 1995; Yanes et al. 1995; Rodriguez et al. 1996; van Wieren and Worm 2001; Ng et al. 2004). Such studies have demonstrated that a broad range of species use wildlife crossing structures, that the optimal design and placement of crossing structures is often species-specific and that crossing rates depend on both landscape and structural features (Rodriguez et al. 1997; McDonald and St-Clair 2004; Clevenger and Waltho 2005; van Vuurde and van der Grift 2005; Grilo et al. 2008). On the other hand, comparatively few studies (see overview in van der Ree et al. 2007) have addressed the extent to which the barrier effect of roads and road-related mortalities is reduced (Lehnert and Bissonette 1997; Dodd et al. 2004; Klar et al. 2009) or gene flow between populations has been enhanced by road mitigation measures (Corlatti et al. 2009; Clevenger and Sawaya 2010). Empirical studies that examine population-level effects of crossing structures are even rarer (but see, e.g., Mansergh and Scotts 1989; van der Ree et al. 2009). Clearly, estimates of the extent to which a structure is used does not directly answer the question of to what extent the impacts of the road and traffic on wildlife have been mitigated.

The paucity of studies directly examining the effectiveness of crossing structures on wildlife populations is exacerbated by the fact that such studies invariably permit, at best, weak inference. For example, many studies are of too short duration to distinguish transient from long-term effects. Only a small number of studies have employed a before-after design or included comparisons between treated and untreated sites (van der Ree et al. 2007; Glista et al. 2009). Consequently, transportation agencies can rarely assess whether mitigation objectives have been met. Without well performed evaluations of the effectiveness of road mitigation measures, we may endanger the viability of wildlife populations and waste financial resources by installing structures that are not as effective as we think 
they are. Furthermore, we cannot establish a set of best mitigation practices nor evaluate cost-benefits and consider what mitigation strategies are most efficient until effectiveness has been quantified.

Here we propose a methodological framework for evaluating the effectiveness of wildlife crossing structures. First, we identify the principle ecological objectives of crossing structures and discuss what needs to be measured to evaluate how well these objectives are being met. Second, we provide guidelines for study design, the selection of appropriate research sites, survey methods and the development of suitable/feasible sampling schemes. For cases where the mitigation is intended to benefit many species, we identify criteria to prioritise species for evaluation. Finally, we discuss the value of road mitigation evaluation for policy makers and transportation agencies and provide recommendations on how to incorporate evaluations into road planning practice.

\section{Guidelines for evaluating road mitigation effectiveness}

The first step in setting up a monitoring plan for evaluating the effectiveness of wildlife crossing structures (Fig. 1) is to determine the species targeted by the mitigation and to explicitly identify mitigation goals. The second step is to identify the species and goals that will actually be evaluated, in cases where it is not feasible to evaluate all species or goals. Steps three to five address the selection of variables to measure, the selection of a study design, and the development of a suitable sampling scheme. Steps six to eight address the selection of appropriate study sites, the determination of appropriate covariates, and the selection of appropriate survey methods. The final step is an assessment of the costs of evaluation and the feasibility of monitoring.

Although the steps in Fig. 1 are suggested as a logical sequence, in reality it may sometimes be necessary to revisit earlier steps to reconsider prior decisions. For example, if no appropriate study sites can be found for a selected species, an alternative study design, measure or species must be selected. Or if the cost of a study surpasses the available budget, alternative decisions on, e.g., study design or survey method should be made. Such iterations in the process may occur from step five onward (Fig. 1), but should be kept to a minimum.

Step 1: Identify species and goals for mitigation

The first step is to identify the target species that prompted the mitigation and formulate the specific goals for mitigation. A list of target species is usually presented by the road authority responsible for the mitigation, often prepared in cooperation with other stakeholders such as wildlife managers and environmental planners. These lists may be based on (1) empirical studies, e.g., on road-kill or road-related changes in animal movements; (2) predictive (modeling) studies in which potential effects of mitigation measures are explored; and/or (3) expert-opinion. Occasionally, groups of species are targeted for mitigation, e.g., "small mammals", "butterflies", or "frogs". This typically occurs as a result of expert opinion or when information is lacking. In such cases, a first step should be to specify targeted species to allow for an effective monitoring plan (van der Grift et al. 2009a).

Selection of target species for mitigation is based on considerations of human safety, animal welfare, and wildlife conservation. Human safety issues dominate when animalvehicle collisions pose a significant risk to motorists. These species need not be of conservation concern. For example the construction of fences and wildlife crossing structures on Swedish highways is motivated primarily by concerns for human health risks associated 


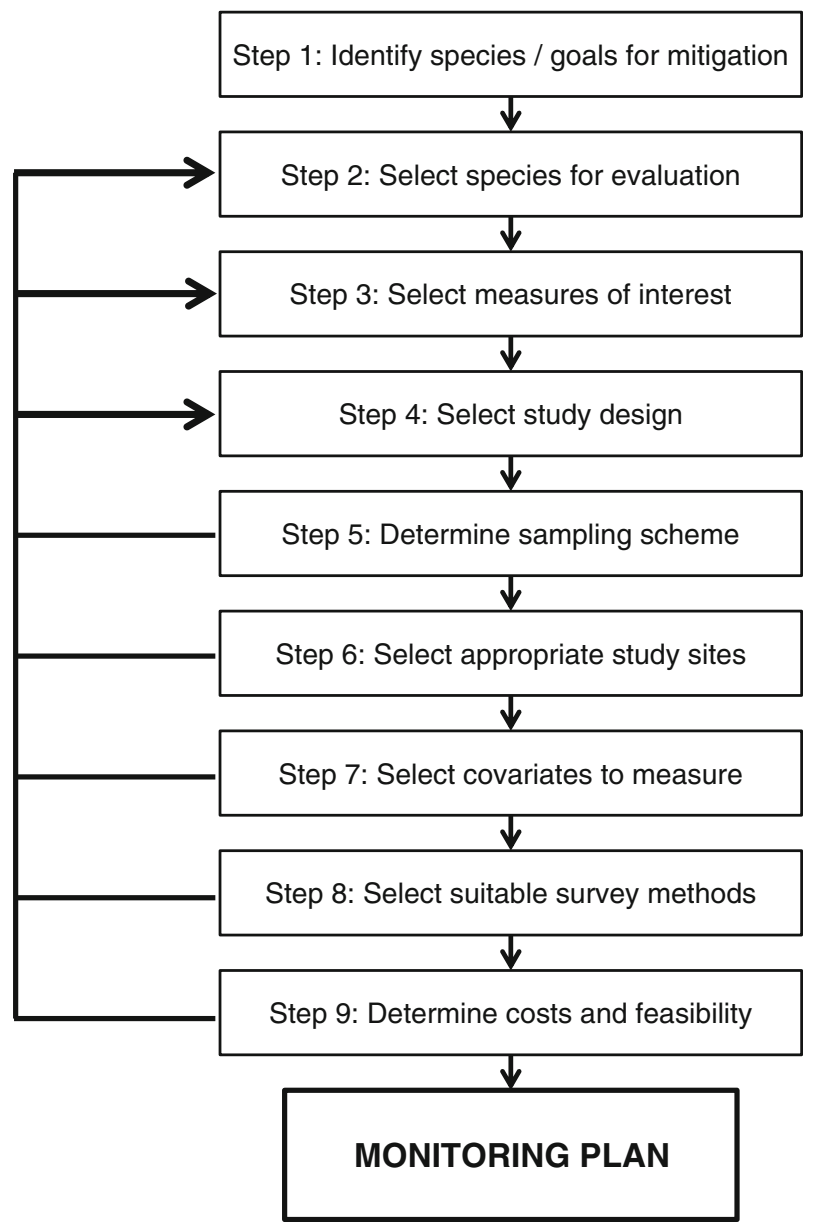

Fig. 1 Process for setting up a monitoring plan for evaluating the effectiveness of wildlife crossing structures

with moose-vehicle collisions rather than a concern with the impacts of traffic mortality on the viability of moose populations (Seiler 2003). When animal welfare drives the selection of species, the motivation is that each animal affected by the road is one too many. For example, the death of high numbers of hedgehogs on Dutch roads is-although the survival probability of local populations may be affected (Huijser and Bergers 2000)—usually not believed to affect the existence of the species in the country, but if animal welfare is a concern, wildlife fences and crossing structures may be warranted. If wildlife conservation is the goal, target species for mitigation are selected on the basis of the potential impact of the road and traffic on species viability, e.g., determined through population modelling. This can include species with protected status as well as species of general conservation concern. Such species selection is generally directed by conservation legislation or environmental policies.

We distinguish two potential targets in road mitigation goals: (1) no net loss, and (2) limited net loss. No net loss implies that road impacts will be entirely mitigated, i.e., the 
post-mitigation situation for the targeted species and goals is identical to the pre-road construction situation. Limited net loss implies that a limited road impact will be accepted (van der Grift et al. 2009a). The target level should be decided in advance and will depend on the local situation. For example, in one jurisdiction a species may be common and its survival not significantly harmed by a small loss in cross-road movements, whereas somewhere else it may be essential to its survival, justifying a no net loss target. In case a limited net loss target level is selected, it should be carefully determined how much loss, relative to pre-road conditions, is acceptable. If this appears hard to pin-point, precautionary principles should be followed, i.e., no net loss should be selected as target level.

Currently, road mitigation studies rarely specify mitigation goals (see van der Ree et al. 2007). When goals are made explicit they are often too imprecise to allow for an evaluation of whether indeed they have been achieved, e.g., "allowing animal movement", "restoring connectivity" and/or "promoting gene flow". Effective evaluation of road mitigation measures requires a clear definition of success. We recommend the SMART-approach to develop goals that are Specific, Measurable, Achievable, Realistic and Time-framed (Doran 1981; examples in Table 1). The goals should ideally: specify what road impact(s) is/are addressed; quantify the reduction in road impact(s) aimed for; be agreed upon by all stakeholders; match available resources; and specify the time-span over which the reductions in road impact(s) have to be achieved. Well-described mitigation goals will channel the choices in the next steps towards an effective monitoring plan (Fig. 1).

Table 1 Examples of SMART defined goals for mitigation for each target level in road mitigation and some of the main road effects addressed by the construction of wildlife crossing structures

\begin{tabular}{|c|c|c|}
\hline \multirow[t]{2}{*}{ Road effect } & \multicolumn{2}{|l|}{ Target level in road mitigation } \\
\hline & No net loss & Limited net loss \\
\hline $\begin{array}{l}\text { Wildlife } \\
\text { mortality }\end{array}$ & $\begin{array}{l}\text { In year } \mathrm{X} \text { after mitigation all traffic-related } \\
\text { mortality of species } \mathrm{Y} \text { is prevented }\end{array}$ & $\begin{array}{l}\text { In year } \mathrm{X} \text { after mitigation } \mathrm{Z} \% \text { of traffic- } \\
\text { related mortality of species } \mathrm{Y} \text { is prevented }\end{array}$ \\
\hline \multirow[t]{5}{*}{$\begin{array}{l}\text { Barrier } \\
\text { effect }\end{array}$} & $\begin{array}{l}\text { In year } \mathrm{X} \text { after mitigation the number of } \\
\text { between-population movements across the } \\
\text { road of species } \mathrm{Y} \text { is similar to pre-road } \\
\text { construction movement numbers }\end{array}$ & $\begin{array}{l}\text { In year } \mathrm{X} \text { after mitigation the number of } \\
\text { between-population movements across the } \\
\text { road of species } \mathrm{Y} \text { is } \mathrm{Z} \% \text { of pre-road } \\
\text { construction movement numbers }\end{array}$ \\
\hline & $\begin{array}{l}\text { Or, if before mitigation the species occurs on } \\
\text { only one side of the road: }\end{array}$ & $\begin{array}{l}\text { Or, if before mitigation the species occurs on } \\
\text { only one side of the road: }\end{array}$ \\
\hline & $\begin{array}{l}\text { In year } \mathrm{X} \text { after mitigation the empty habitat } \\
\text { is permanently colonised by species } \mathrm{Y}\end{array}$ & $\begin{array}{l}\text { In year } \mathrm{X} \text { after mitigation the empty habitat is } \\
\text { used } \mathrm{Z} \% \text { of the time by species } \mathrm{Y}\end{array}$ \\
\hline & $\begin{array}{l}\text { Or, if before mitigation the populations on } \\
\text { both sides of the road show significant } \\
\text { genetic differences: }\end{array}$ & $\begin{array}{l}\text { Or, if before mitigation the populations on } \\
\text { both sides of the road show significant } \\
\text { genetic differences: }\end{array}$ \\
\hline & $\begin{array}{l}\text { In year } \mathrm{X} \text { after mitigation no genetic } \\
\text { difference occurs between populations of } \\
\text { species } \mathrm{Y} \text { across the road }\end{array}$ & $\begin{array}{l}\text { In year } \mathrm{X} \text { after mitigation the genetic } \\
\text { difference between populations of species } \\
\mathrm{Y} \text { across the road is reduced by } \mathrm{Z} \%\end{array}$ \\
\hline \multirow[t]{3}{*}{$\begin{array}{l}\text { Population } \\
\text { reduction }\end{array}$} & $\begin{array}{l}\text { In year } \mathrm{X} \text { post-mitigation population density } \\
\text { of species } \mathrm{Y} \text { is similar to pre-road } \\
\text { construction population density }\end{array}$ & $\begin{array}{l}\text { In year X post-mitigation population density } \\
\text { of species } Y \text { reaches } Z \% \text { of pre-road } \\
\text { construction population density }\end{array}$ \\
\hline & $\begin{array}{l}\text { Or, if pre-road construction situation is } \\
\text { unknown: }\end{array}$ & $\begin{array}{l}\text { Or, if pre-road construction situation is } \\
\text { unknown: }\end{array}$ \\
\hline & $\begin{array}{l}\text { In year X post-mitigation population density } \\
\text { of species } \mathrm{Y} \text { is similar to population density } \\
\text { in a control population }\end{array}$ & $\begin{array}{l}\text { In year X post-mitigation population density } \\
\text { of species } \mathrm{Y} \text { reaches } \mathrm{Z} \% \text { of population } \\
\text { density in a control population }\end{array}$ \\
\hline
\end{tabular}


Step 2: Select species for evaluation

The preferred approach is to study the responses of all species targeted for mitigation. However, the list of targeted species is often long and resources may not be sufficient to evaluate them all. It may also not be necessary to evaluate all targeted species, as some may be similar to others in their responses to roads and road mitigation. Hence, the species for evaluation need to be chosen, and a random sampling approach may be required if the general performance of a wildlife crossing structure needs to be assessed. However, studies of the performance of wildlife crossing structures usually target threatened species, i.e., species that are rare, in decline or both. If limited resources prevent an evaluation of all threatened species, one may choose species that are most likely to demonstrate statistically significant effects with comparatively little sampling effort in space and/or time. We suggest using the following criteria to select those species: (1) Select species that have shown strong responses to roads and traffic, e.g., species that are frequently killed by traffic, or species that have proven to be unable/reluctant to cross roads or who avoid the road corridor altogether (see also Jaeger et al. 2005). (2) Select species that are expected to show short response times to road mitigation, e.g., species that quickly habituate to wildlife crossing structures. (3) Select species that are relatively widespread, as this will increase opportunities to find suitable replication and control sites. (4) Select species with low natural variability in population densities over time, as high variability in population densities will decrease the statistical power to detect road mitigation effects. (5) Select species that can be readily and easily surveyed. If the list of selected species for evaluation, after applying these criteria, still exceeds available resources, further selections of species can be made on the basis of preferences, for example, even representation of different animal taxa, habitats and/or trophic levels.

\section{Step 3: Select measures of interest}

As Table 2 shows there are many ways to measure road mitigation effectiveness, depending on the concern, i.e., human safety, animal welfare or wildlife conservation. The best measures, i.e., measurement endpoints, are those which are most closely related to the outcome(s) of real concern, i.e., the assessment endpoint (Suter 1990; Roedenbeck et al. 2007). For example, (changes in) population viability cannot be directly measured in the field, hence we measure attributes of the population that are known to be related to population viability and predict future likelihood of persistence.

Four measurement endpoints are suggested to assess effects of road mitigation measures on human casualties (Table 2). The best is the actual number of people killed or injured due to animal-vehicle collisions or due to collision avoidance. Alternative measurement endpoints include the amount of insurance money spent, number of hospitalizations due to animal-vehicle collisions or collision avoidance, or number of wildlife-vehicle collisions concerning species that potentially impact human safety, regardless of whether they resulted in human injury or death. Two measurement endpoints are suggested to assess effects of road mitigation measures on wildlife health and mortality, i.e., the number of animals killed or injured while crossing roads and the number of animals killed or with illhealth due to isolation from needed resources through the barrier effect of roads (Table 2). These measurement endpoints seem to complement each other as each endpoint addresses a different mechanism through which wildlife health and mortality can be positively affected by wildlife crossing structures, i.e., through a reduction in animal-vehicle collisions or through increased road permeability and hence increased access to resources. Therefore, we suggest to always use these endpoints together. 
Table 2 Overview of possible measurement endpoints (list is not complete) for each driver of road mitigation and assessment endpoint, and the extent of extrapolation needed from measurement endpoint to assessment endpoint

\begin{tabular}{|c|c|c|c|}
\hline $\begin{array}{l}\text { Driver of road } \\
\text { mitigation }\end{array}$ & $\begin{array}{l}\text { Assessment } \\
\text { end point } \\
\text { What we } \\
\text { want to } \\
\text { know }\end{array}$ & $\begin{array}{l}\text { Measurement endpoint } \\
\text { What we measure }\end{array}$ & $\begin{array}{l}\text { Extent of } \\
\text { extrapolation } \\
\text { needed from } \\
\text { measurement to } \\
\text { assessment endpoint }\end{array}$ \\
\hline \multirow[t]{4}{*}{ Human safety } & $\begin{array}{l}\text { Human } \\
\text { casualties }\end{array}$ & $\begin{array}{l}\text { Number of humans killed or injured due to wildlife- } \\
\text { vehicle collisions or due to collision avoidance }\end{array}$ & 0 \\
\hline & & $\begin{array}{l}\text { Insurance money spent on material/immaterial } \\
\text { damage due to wildlife-vehicle collisions }\end{array}$ & $* *$ \\
\hline & & $\begin{array}{l}\text { Number of hospitalizations due to vehicle-animal } \\
\text { collisions }\end{array}$ & $* *$ \\
\hline & & $\begin{array}{l}\text { Number of wildlife-vehicle collisions, concerning } \\
\text { species that potentially impact human safety, } \\
\text { regardless of whether they resulted in human } \\
\text { injury or death }\end{array}$ & $* * * *$ \\
\hline \multirow[t]{2}{*}{$\begin{array}{l}\text { Animal } \\
\text { welfare }\end{array}$} & $\begin{array}{l}\text { Wildlife } \\
\text { health and } \\
\text { mortality }\end{array}$ & $\begin{array}{l}\text { Number of animals killed or injured while crossing } \\
\text { roads }\end{array}$ & 0 \\
\hline & & $\begin{array}{l}\text { Number of animals killed or with ill-health due to } \\
\text { isolation from needed resources through the } \\
\text { barrier effect of roads }\end{array}$ & 0 \\
\hline \multirow[t]{8}{*}{$\begin{array}{l}\text { Wildlife } \\
\text { conservation }\end{array}$} & $\begin{array}{c}\text { Population } \\
\text { viability }\end{array}$ & Trend in population size/density & $*$ \\
\hline & & Number of animals killed & $* *$ \\
\hline & & Reproductive success & $* *$ \\
\hline & & Age structure & $* * *$ \\
\hline & & Sex ratio & $* * *$ \\
\hline & & Between-population movements & $* * *$ \\
\hline & & Genetic differentiation & $* * * *$ \\
\hline & & Genetic variability & $* * * *$ \\
\hline
\end{tabular}

Needed extrapolation is classified as not needed $(0)$, low $(*)$, moderate $(* *)$, high $(* * *)$, or very high $(* * * *)$

Eight measurement endpoints are suggested to assess effects of road mitigation measures on population viability (Table 2). The most informative measurement endpoint is the trend over time in the size (or density) of the local population. Trend in population size is fundamental to understanding how the species has responded to the road mitigation. For example, if existing roads are having population-level effects and crossing structures are successful in mitigating those effects we would expect to see increases in population size after the structures are installed. If the crossing structures are installed on a new road, successful mitigation would be indicated by no change in the size of the wildlife population. Population size itself is also related to population persistence, since smaller populations are more likely to go extinct by chance.

When it is not possible to estimate population size or trend, a reduction in road-kill numbers following mitigation may provide an indicator for mitigation effectiveness at population level, but only if compared with road-kill numbers at control sites (see also Step 4) and if assumed (which may not hold) that (1) mortality is the main mechanism through which roads affect the population, and (2) road-induced mortality is not counteracted by, 
e.g., increased reproduction or immigration. As both assumptions may not apply (but see Hels and Buchwald 2001), changes in road-kill numbers should be seen as less indicative than estimates of population size or trend. Similarly, reproductive success as an indicator for mitigation effectiveness at the population level should be used with care, as no increase in reproductive success following mitigation may be the result of higher reproduction levels pre-mitigation as a response to loss of individuals due to road mortality.

Age structure and sex-ratio within the population may provide additional information to supplement the estimate of trends in population size because roads may impact individuals of different age classes or sexes differently. A positive feature of these measurement endpoints is that changes may be detected sooner in population structure than in population trend. However, they are less closely tied to population viability so more extrapolation is necessary, and they are only applicable to species that show differential age or sex responses to the road or traffic.

Road permeability measurement endpoints, such as between-population movement and gene flow may also allow inferences to population-level mitigation, if the main populationlevel effect of the road is through movement (rather than, say, mortality). Increased movements between populations divided by roads may affect, e.g., dispersal success or access to mates (see, e.g., Mansergh and Scotts 1989) and consequently population dynamics. Migrations across wildlife crossing structures may restore gene flow and reduce road-related genetic differences between the populations (Gerlach and Musolf 2000; Vos et al. 2001; Epps and McCullough 2005; Arens et al. 2007; Björklund and Arrendal 2008; Balkenhol and Waits 2009; Corlatti et al. 2009). Although both measurement endpoints directly address the extent to which the barrier effect of roads is reduced, endpoint extrapolation is rather high because demographic and genetic connectivity between populations are not necessarily related to population viability.

An even less direct indicator of a change in population viability is a change in genetic variability within the population. Genetic variability is thought to be positively correlated with population viability (Frankham 1996, 2005; Lacy 1997; Reed and Frankham 2003; Reed et al. 2007). Small populations that result from increased mortality or habitat fragmentation lose genetic variability as a result of genetic drift or inbreeding (Keller and Largiader 2003). The disadvantage of genetic variability as an endpoint is that the correlation between genetic variability and population persistence is not well understood. However, changes in genetic diversity - as an important part of biodiversity-may in itself be considered as an assessment endpoint.

\section{Step 4: Select study design}

Appropriate study design, i.e., the spatial and temporal sampling scheme, is critical for determining the effectiveness of road mitigation. It is the responsibility of the ecologists involved in the research and monitoring process to ensure the design is rigorous and provides useful information. As argued by Roedenbeck et al. (2007), the optimal study design is a replicated BACI (Before-After-Control-Impact), where data are collected before and after road mitigation, both at sites where mitigation measures are being taken (impact sites-hereafter referred to as mitigation sites) and at sites that are similar to these sites but where no mitigation measures are taken (control sites).

Control sites are important to ensure that changes to the measurement endpoint can reasonably be attributed to the mitigation measures. For example, mitigation may reduce road-kill, but an observed reduction in road-kill could also be caused by other factors, such as a decrease in population density, increased road avoidance behavior or changes in traffic 
volume. An important assumption here is that mitigation and control sites are similar in all relevant respects (see also Step 6). As this assumption is rarely met, replication is strongly recommended for both the mitigation and control sites. We also recommend including unconventional controls or benchmarks that may further help to interpret observed changes, such as reference areas that are characterized by the absence of roads, or measurements of (national) trends in the selected measurement endpoints over time.

In some situations, there may be no suitable control sites available. Under these conditions, a replicated BA study design (Before-After) may be an alternative, where measurements are taken at multiple sites before and after the treatment. The fundamental limitation of this design is that an observed change in the measurement endpoint may have been caused by some factor other than the road mitigation. Since the BA design fails to distinguish other sources of temporal variability from effects of the mitigation measures, other potential impact factors (e.g., climate variability, increasing traffic volume over time) should be considered when interpreting the results (Roedenbeck et al. 2007).

In some other situations, such as when the effectiveness of an existing wildlife crossing structure is to be quantified, it may be impossible to collect any 'before' data. Under these conditions, a replicated CI study design (Control-Impact) may be possible, where measurements are taken at multiple mitigation and control sites after mitigation. The inference in a CI design is that differences between the mitigation and control sites are due to the mitigation measure. However, as no two sites are identical, this inference may be invalid if the observed effect arises from other systematic differences between control and impact sites, or possibly even random inter-site variation. Replication of both the mitigation and control sites increases the strength of the inference that observed differences are indeed due to the mitigation. Note that the level of replication required for a CI study is higher than the level of replication required for a BACI type of study.

When selecting an appropriate study design, opportunities for experimental manipulations should be explored, as this may provide higher inferential strength. For example, if the construction of wildlife crossing structures along one road can be staged, the temporarily non-mitigated stretch can be used as control site. Or when a time gap can be planned between the construction of wildlife fences and the construction of crossing structures or some of the crossing structures can be closed intentionally for a while after construction, the individual effects of both measures can be evaluated. Such an approach requires that goals and plans for evaluations are incorporated into the construction schedule.

\section{Step 5: Determine sampling scheme}

Several key questions related to data collection should now be addressed: (1) How long should sites be monitored before and after road mitigation? (2) How often should sites be monitored? (3) How many replicates are needed? As these decisions are unlikely to be independent, we recommend conducting model-based power analyses to optimize the sampling design (see, e.g., van der Grift et al. 2009b). For example, Fig. 2 illustrates the relationship between mitigation effectiveness (the expected effect size) on the degree of temporal replication needed for adequate statistical power. Similar graphs can be produced for other design variables such as sampling frequency and the number of replicate sites. Note that either pilot studies or pre-existing data on anticipated effect sizes are needed to conduct this type of analysis.

The sampling scheme is related to the chosen measurement endpoint and the characteristics of the studied species. For example, for a highly mobile species with a long 


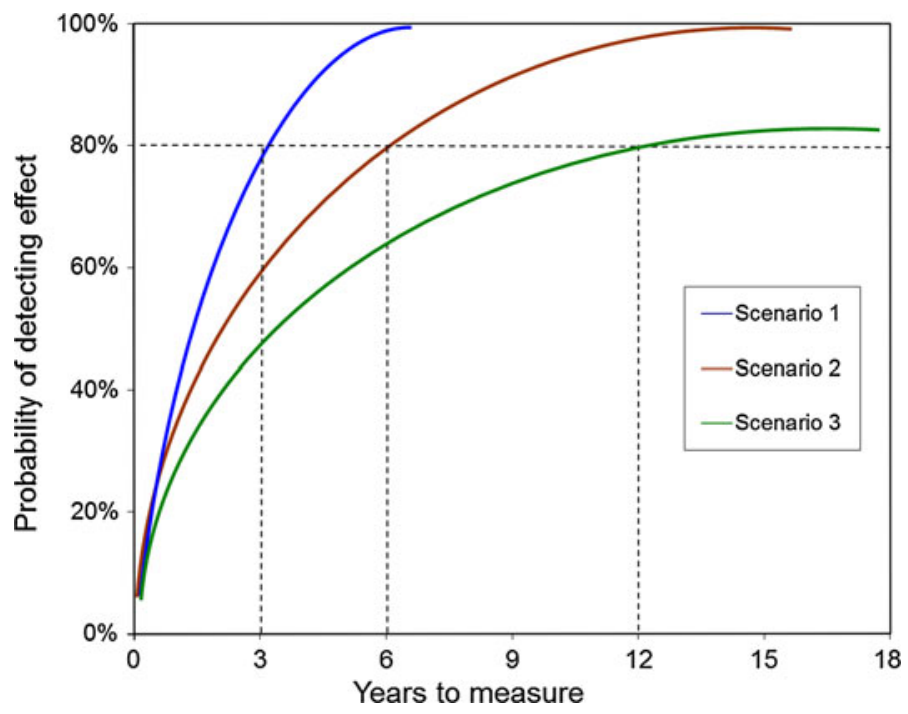

Fig. 2 Hypothetical relation between the probability of detecting an effect of road mitigation and the duration of monitoring after the mitigation measures are put in place. The three scenarios illustrate variations in the expected effectiveness of mitigation, e.g. road mitigation is expected to reduce the road effect by 100,75 or $50 \%$. The figure shows that if we want to achieve statistical power of $80 \%$ we should measure the response variable for 3, 6 and 12 years in scenarios 1, 2, and 3, respectively. This figure assumes that the effect of the mitigation measure on the population is immediate. However, response times of the population to both the road and the mitigation measures also have to be considered

lifespan, monitoring over a longer period would be required to assess a change in population density than that required to detect a change in movement. Similarly, a shorter monitoring period would be required to assess a change in road-kill numbers for a species that crosses roads frequently than for a species that crosses roads infrequently. For some measurement endpoints, such as changes in population size/density, higher levels of replication will allow a quicker evaluation of effectiveness. A study with three replicates will need to be continued for longer than a study with ten replicates, because with more replication the uncertainty in effect size will be reduced, thus allowing a reliable decision to be reached sooner.

The rate of use of wildlife crossing structures often increases over time (e.g., Clevenger and Waltho 2003; Ford et al. 2010) due to habituation or gradual improvement in the quality of the crossing structure (e.g., vegetation succession on wildlife overpasses). If usage and effectiveness are positively correlated, it is also likely that effectiveness will increase with time since mitigation. Therefore, if monitoring ceases too quickly, an incorrect inference that a crossing structure is ineffective may be drawn. In fact, in some cases monitoring resources may be more effectively allocated by waiting for a few years after installation of the mitigation measure before starting the 'after' monitoring. This may be particularly true when the assessment endpoint is population viability. Similarly, monitoring a site for too long commits resources after they are needed. Thus, sampling should not begin before an effect is expected to have occurred and should continue long enough to detect lagged and/or transient effects. A worst-case scenario is that the sampling duration is too short to detect a real effect and that future mitigation projects reject the use of a measure that is, in fact, successful. 
Step 6: Select appropriate study sites

\section{Selection of mitigation sites}

If a road mitigation evaluation is to assess the effectiveness of multiple wildlife crossing structures along a road or hundreds of mitigation sites at multiple roads, it may be necessary to sample a subset of the available mitigation sites. The method for selecting an appropriate subset of mitigation sites depends on the overall objective of the evaluation. If the objective is to evaluate the extent to which a road mitigation plan is effective for a target species, one should choose a random sample of mitigation sites from the total number of available mitigation sites. Such evaluation aims to provide insight into the average effectiveness of the road mitigation. If the objective is, however, to evaluate whether wildlife crossing structures potentially mitigate road impacts for the target species, one should choose sites that are most likely to demonstrate statistically significant effects with comparatively little sampling effort in time. The following criteria provide a framework to select mitigation sites in this context: (1) Select sites where the road effect is known or expected to be high. (2) Select sites where the planned construction of the mitigation measures allows for sufficient time for repeated measurements before construction. (3) Select sites for which sufficient replicate sites can be found. (4) Select sites where multiple mitigation measures are planned for a relatively long section of road as this may allow for phasing or manipulating mitigation in an experimental design (see Step 4 above).

A mitigation effect is most likely to be detectable where a significant positive shift in population viability-e.g., estimated through a PVA (see, e.g., van der Grift and Pouwels 2006) — can be expected as a result of the road mitigation measures (Fig. 3). This implies selecting sites where on at least one side of the road the amount of habitat available is sufficient for only a small, non-viable population that needs an influx of animals from the opposite side of the road (Fig. 3b; see also van der Grift et al. 2002). An impact site with non-viable populations on both sides of the road may be appropriate as well, but only if the combined amount of habitat on both sides of the road is sufficient for a viable overall population in the mitigated situation (Fig. 3c).

The size of a mitigation site, in terms of road length, may vary. Preferably, the mitigation site is delineated where the studied road effect no longer occurs. These boundaries typically occur where suitable habitat ceases. Hence, if more than one target species is studied at one mitigation site, the size of that site, in terms of road length, may differ for each species as habitat preferences differ among species. The size of mitigation sites should not be based on the length over which wildlife fences are planned-as they may only be planned for limited sections of the road. Limiting measurements to only fenced road sections may mean that the conclusions drawn about the effectiveness of the road mitigation measures may be overly positive (Fig. 4).

\section{Selection of control sites}

Control sites require some consideration to ensure the comparison between the mitigation and control sites is valid. The goals for mitigation (see Step 1) determine which type of control site is needed, i.e., either a control site where the road is present but there is no mitigation, or control sites where there is no road present. The former applies when postmitigation conditions have to be compared with pre-mitigation conditions, e.g., when the aim is to compare between-population movements before and after road mitigation. The 


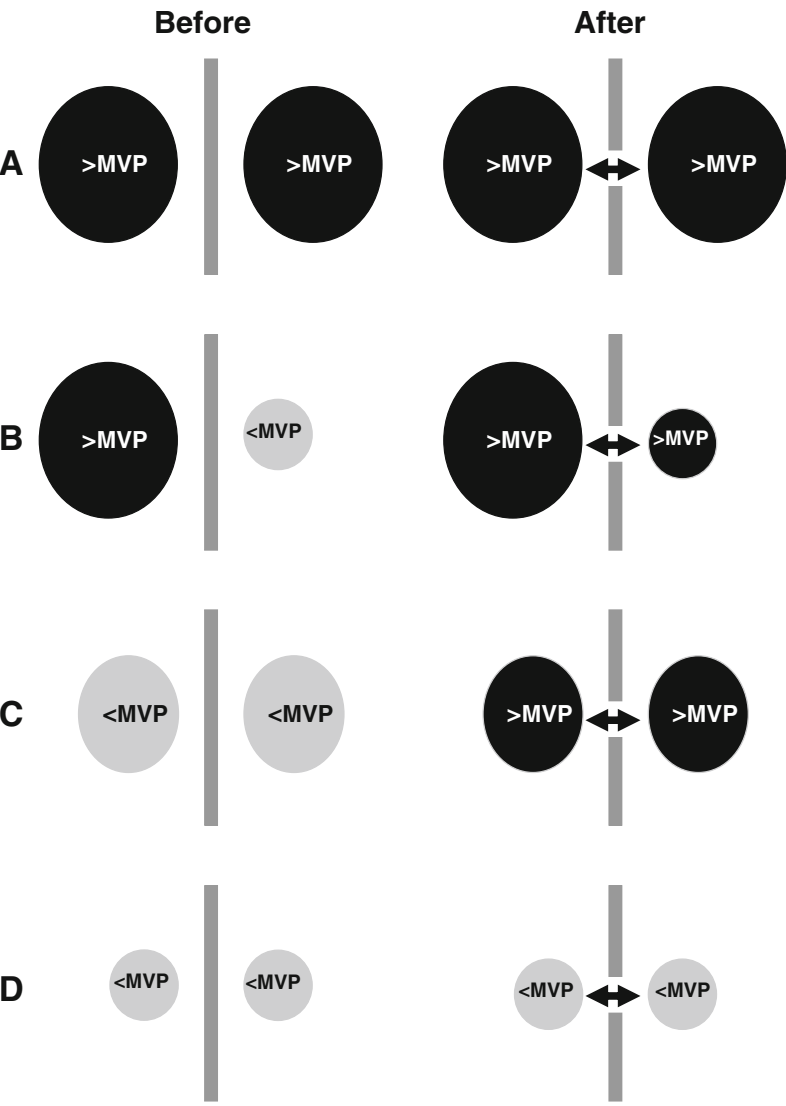

Fig. 3 Schematic overview of consequences for population viability when populations of different size, above or below the threshold of a minimum viable population (MVP), are merged due to road mitigation measures. Viable populations are depicted in black, non-viable populations in grey. Populations in which a significant effect of road mitigation on population viability is expected, here in situation $B$ and $C$, should preferably be selected as research sites

latter applies when post-mitigation conditions have to be compared with pre-road construction conditions. For example, when a no net loss in population size/density is the target. If, in such cases, only control sites where the road is present but without mitigation are selected, no final conclusions can be drawn on the extent to which the full effect of the road has been mitigated.

Figure 5 illustrates measured (changes in) population density over time at mitigation and control sites where there is mitigation of an existing road. Scenarios 1 and 2 show that population density increased with the installation of road mitigation measures. However, proper assessments of the extent to which population density improves can only be made if we include no-road control sites. The other scenarios show no improvement (scenario 3) or even a decline in population density (scenario 4) after mitigation, due to mitigation measures that are ineffective (e.g., not located, designed or managed properly, or too few; compare for example Fig. 4II, IV). Proper assessments of the extent to which population density declines have been mitigated can only be made if we include no-mitigation control sites. Similar scenarios can be constructed for cases where the construction of the road and 
C

I

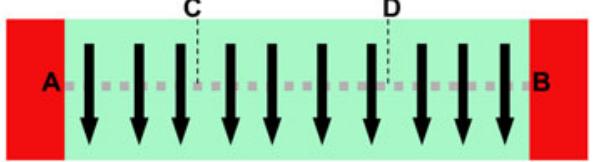

C

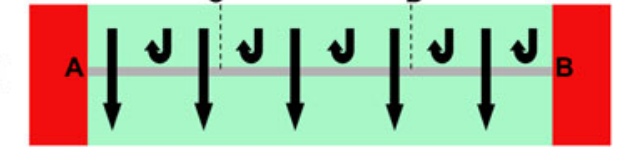

c

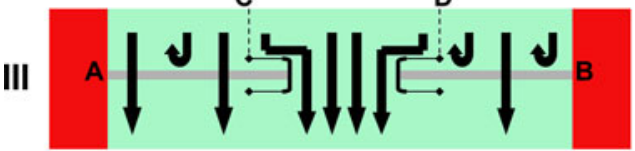

D

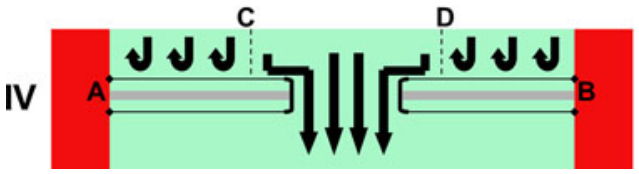

Before road construction

After road construction, no mitigation yet

After road mitigation: one wildlife overpass and wildlife fences between $C-D$

After road mitigation: one wildlife overpass and wildlife fences between A-B

Fig. 4 Example of how the size of a mitigation site, i.e., road length where measurements are carried out, affects conclusions about crossing structure effectiveness. The studied road effect is the reduction of between-population movement. The green area symbolizes suitable habitat for the studied species. Red areas are non-suitable habitat, e.g., urban areas. Road construction (II) has decreased the number of movements by $50 \%$, compared to pre-road conditions $(I)$. If only the mitigated road stretch $(C-D)$ is included in the evaluation (III), the conclusion would be that the crossing structure is $100 \%$ effective, as the number of movements across the road pre-road construction and post-mitigation are equal $(n=4)$. However, if the whole road stretch $(A-B)$ is included in the evaluation, the conclusion would be that the crossing structure is only $70 \%$ effective, as the crossing structure does not provide a solution for all potential movements across the road. Because the aim of the road mitigation was to fully prevent the barrier effect of the road between $A$ and $B$, a delineation of the mitigation site between $C$ and $D$ will overestimate crossing structure effectiveness. Finally, the situation is shown where the full road length is fenced in $(I V)$. In this case the effectiveness of the road mitigation measures is $40 \%$, illustrating that road mitigation, if not properly implemented, i.e., with sufficient numbers of crossing structures along the road, may result in less connectivity between populations on opposite sides of the road in comparison with the situation before mitigation (II). Again, like in situation III, wrong conclusions on mitigation effectiveness would be drawn if only road section $C-D$ was monitored

road mitigation take place simultaneously, except that the trajectories would have a different starting point, i.e., at the level of the no-road control at $t=0$ (Fig. 6).

All control sites need to be far enough away from the mitigation sites and each other to ensure statistical independence, yet still be as similar as possible. If possible, control sites should be sited along the same road as the mitigation site(s), as road age, design and traffic characteristics of the same section of road are probably similar. Such control sites should never immediately border the mitigation site(s), as possible edge effects of mitigation measures, e.g., an unnaturally high number of road-kill just at the end of the wildlife fencing, may influence the measurements.

\section{Select appropriate spatial scale of study}

Two factors need to be considered when determining the spatial scale of a study. First, the spatial scale of the study should match the spatial scale of the effect being mitigated. Stipulating a one-size fits all approach to determine the spatial scale of the study is not 


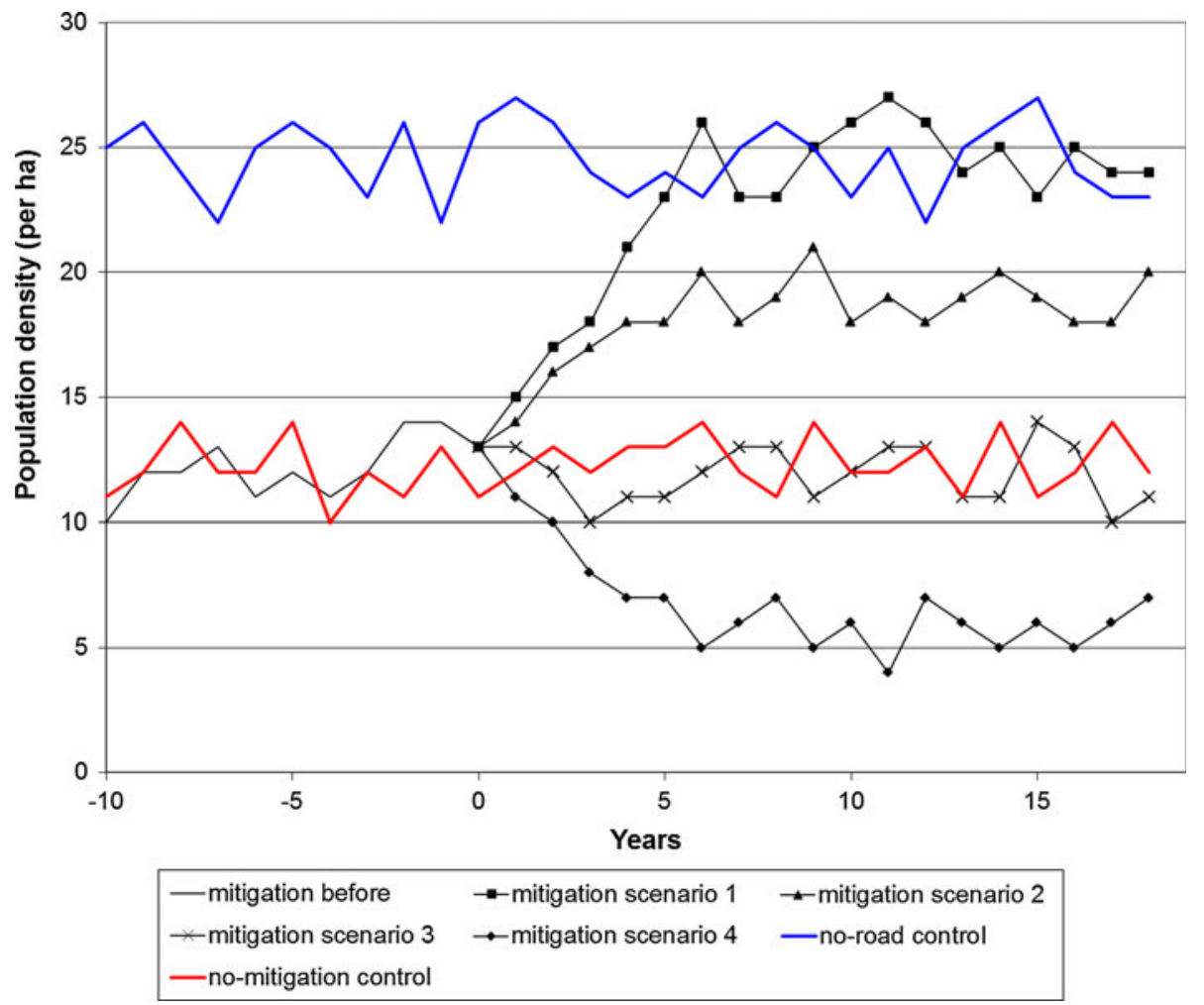

Fig. 5 Hypothetical result when evaluating the effectiveness of road mitigation measures at an existing road. Mitigation measures are installed at time zero. In addition to the mitigation site, measurements are carried out-before and after mitigation-at a no-mitigation control site and a no-road control site. Generally, there are four possible scenarios 1 the road mitigation measures are $100 \%$ effective and population density increases to the level of the no-road control site, 2 the road mitigation measures are only partly effective and population density increases compared to the unmitigated situation but does not reach the level of the no-road control site, 3 the road mitigation measures are not effective and population density remains similar to the density in the unmitigated situation, 4 the road mitigation measures are not effective and even worsen the situation by reducing population density compared to the unmitigated situation

possible because the size of the road effect zone (Forman and Deblinger 2000; Forman et al. 2003) varies depending on the effect, the species of concern, and the local situation (e.g., habitat type, topography). Second, the sampling effort should be apportioned equally across the road effect zone, as the road effect of concern may vary significantly within this zone. The effect-size of the road-and consequently the effect-size of road mitigation measures-will be often at its maximum in close proximity to the road. However, situations occur where the opposite is true, e.g., due to an increase in suitable edge habitat at the roadside (Mumme et al. 2000) or due to home range pile-up adjacent to the road due to barrier effects (Riley et al. 2006).

It is often necessary to do a best guess about where the road effect zone ends. The distance over which an individual moves-on a daily basis or over its life span-may be helpful here, but should not be viewed as a characterization of the appropriate spatial scale of all studies. If changes in between-population movements are studied, mean individual movement distances may well indicate the effect-distance, as individuals that live farther 


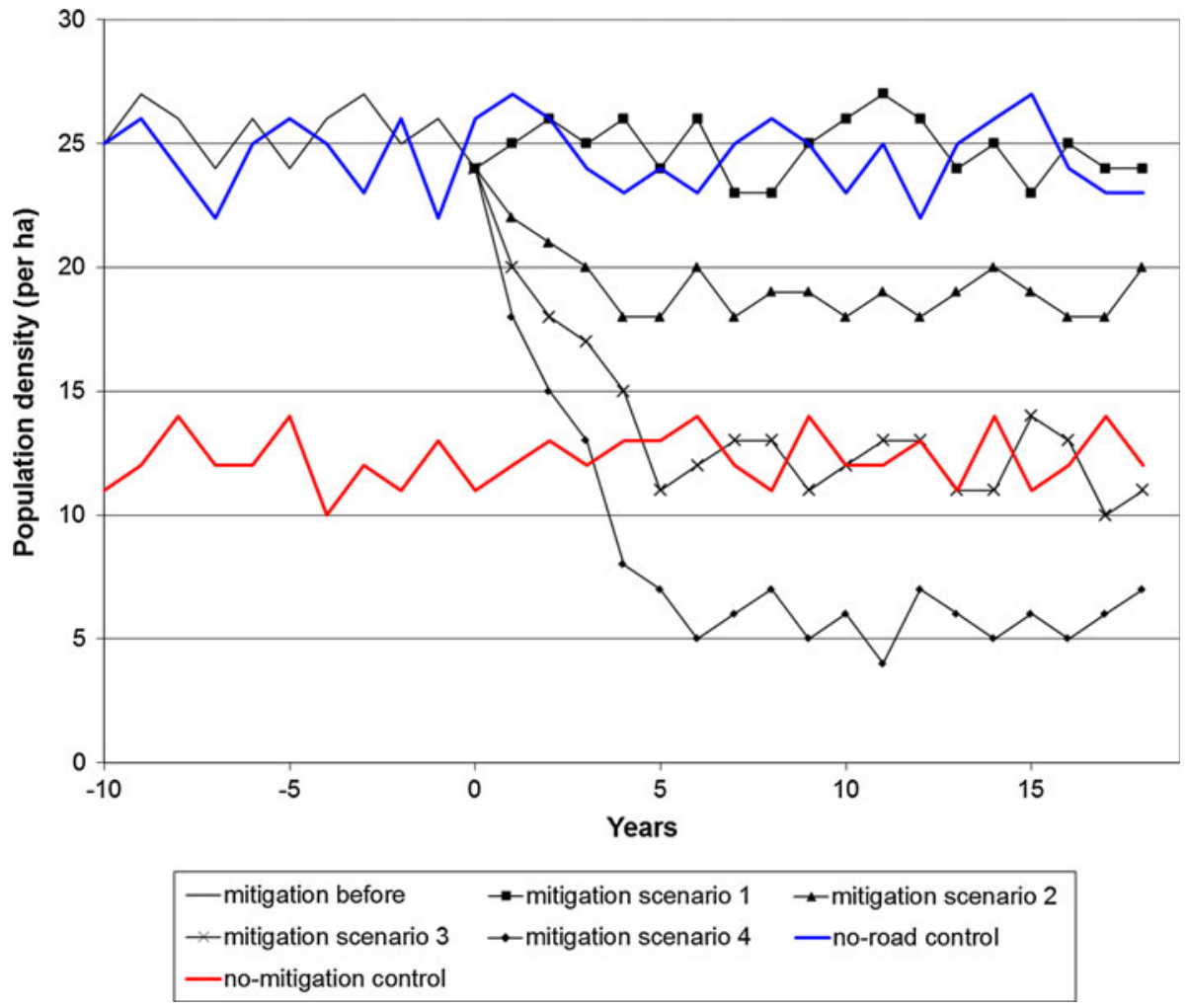

Fig. 6 Hypothetical result when evaluating the effectiveness of road mitigation measures at a new road with mitigation. The new road with mitigation is constructed at time zero. In addition to the mitigation site, measurements are carried out-before and after road construction-at a no-mitigation control site and a noroad control site. Generally, there are four possible scenarios 1 the road mitigation measures are $100 \%$ effective and population density remains at the level of the no-road control site, 2 the road mitigation measures are only partly effective and population density decreases compared to the no-road control site but does not reach the level of the no-mitigation control site, 3 the road mitigation measures are not effective and population density decreases to the level of the no-mitigation control site, 4 the road mitigation measures worsen the situation and population density decreases below the level of the no-mitigation control site

from the road than the mean individual movement distance will not likely reach the road corridor and road mitigation measures. However, if genetic features are studied, individual movement distances are not suitable indicators for the effect-distance, as the genetic changes will diffuse from the local area adjacent to the road and indirectly affect the broader population over time. The same applies if population size/density is the selected measurement endpoint. In cases where little is known about the spatial extent of road or road mitigation effects, as will often be the case, or where cumulative effects of multiple roads are expected, sampling should be done at multiple spatial scales.

Step 7: Select covariates to measure

Sampling should not just be limited to the selected measurement endpoint. Other variables should also be measured to improve interpretation of the results, provide better comparisons among study sites, and allow for stronger inferences concerning the causes of 
observed differences. We recommend documenting spatial (among sites, where appropriate) and/or temporal (within sites over time, where appropriate) variability in: (1) road design and traffic, (2) crossing structure design and use, and (3) structural features of the surrounding landscape, all of which have been shown to influence the use of road mitigation measures (Clevenger and Waltho 2000; McDonald and St-Clair 2004; Ng et al. 2004; Clevenger and Waltho 2005; van Vuurde and van der Grift 2005; Ascensão and Mira 2007; Grilo et al. 2008).

Road design covariates should include road width, road surface elevation (elevated road bed or road bed in cut), presence and type of pavement, presence and type of street lights, presence and type of fences, presence and type of noise screens, presence and width of median strip, presence and type of barriers in the median strip, presence and width of road verges, and presence and type of vegetation in road verges. Traffic volume and speed should be documented at several temporal scales (e.g., daily, seasonally, annually). Road mitigation covariates should include size and characteristics of the crossing structures, the type and size of wildlife fences, passage use by the target species and non-target species, and presence and frequency of use by humans and domestic animals. Information on the duration of the construction period that marks the transition from the 'before' to the 'after' situation and the date that road mitigation measures were ready for use may also be important. Finally, landscape covariates should include the altitude, topography, land use, type and amount of vegetation and the occurrence of characteristic landscape elements (e.g., river, pond, hedge row).

Step 8: Select suitable survey methods

For most measurement endpoints, several survey methods exist (Table 3) but not all methods are equally effective for all species or species groups. We recommend survey methods that monitor multiple species simultaneously to provide more information for similar effort. We also recommend using more than one survey method for each species, because combining methods can decrease bias and provide better estimates of the variable of interest. Consistent use of the same methods and personnel over time and across control/ mitigation sites is important to provide comparable results.

\section{Step 9: Determine costs and feasibility}

A comprehensive evaluation of road mitigation measures will require a substantial budget. However, other resources that may not have direct costs are equally important, e.g., sufficient time, or stakeholder support. The need for both economic and non-economic resources demands detailed organization and planning, including clear deadlines for decisions, and strong consensus among the research team, the funding organization and other stakeholders. For example, if a land owner refuses access to a sampling site during a long-term study, resources spent on sampling that location will have been wasted.

If all necessary resources cannot be guaranteed before commencing the project, carrying out the study should be seriously reconsidered. Hence, we recommend conducting a comprehensive risk assessment before the start of a study, to judge its feasibility. Such risk assessment should not only address costs, but all types of resources needed for the study, including risks related to the research itself. As road mitigation evaluation studies are ambitious, especially those that aim for measuring effects on population viability, unexpected complications are likely to arise and thus uncertainties should be incorporated into cost and scheduling estimates. For example, a selected study site may become unsuitable 
Table 3 Potential survey method(s) for each measurement endpoint

\begin{tabular}{|c|c|c|}
\hline $\begin{array}{l}\text { Assessment } \\
\text { endpoint }\end{array}$ & Measurement endpoint & Potential survey methods \\
\hline \multirow[t]{4}{*}{$\begin{array}{l}\text { Human } \\
\text { casualties }\end{array}$} & $\begin{array}{l}\text { Number of humans killed or injured due to } \\
\text { wildlife-vehicle collisions or due to } \\
\text { collision avoidance }\end{array}$ & Questionnaire \\
\hline & $\begin{array}{l}\text { Insurance money spent on material/ } \\
\text { immaterial damage due to wildlife-vehicle } \\
\text { collisions }\end{array}$ & Questionnaire \\
\hline & $\begin{array}{l}\text { Number of hospitalizations due to vehicle- } \\
\text { animal collisions }\end{array}$ & Questionnaire \\
\hline & $\begin{array}{l}\text { Number of wildlife-vehicle collisions, } \\
\text { concerning species that potentially impact } \\
\text { human safety, regardless of whether they } \\
\text { resulted in human injury or death }\end{array}$ & Road surveys \\
\hline \multirow{2}{*}{$\begin{array}{l}\text { Wildlife } \\
\text { health and } \\
\text { mortality }\end{array}$} & $\begin{array}{l}\text { Number of animals killed or injured while } \\
\text { crossing roads }\end{array}$ & Road surveys \\
\hline & $\begin{array}{l}\text { Number of animals killed or with ill-health } \\
\text { due to isolation from needed resources } \\
\text { through the barrier effect of roads }\end{array}$ & Field surveys \\
\hline \multirow[t]{8}{*}{$\begin{array}{l}\text { Population } \\
\text { viability }\end{array}$} & Trend in population size/density & $\begin{array}{l}\text { Capture-mark-recapture, Point/Transect } \\
\text { counts or calling surveys, Pellet counts, } \\
\text { Nest/den counts, Tracking arrays, e.g. } \\
\text { photo/video cameras, track pads }\end{array}$ \\
\hline & Number of animals killed & Road surveys \\
\hline & Reproductive success & Counts of eggs/young \\
\hline & Age structure & Capture, Direct observation \\
\hline & Sex ratio & Capture, Direct observation \\
\hline & Between-population movements & $\begin{array}{l}\text { Capture-Mark-Recapture, Radio-tracking, } \\
\text { Direct observation, Tracking arrays }\end{array}$ \\
\hline & Genetic differentiation & $\begin{array}{l}\text { Invasive DNA sampling after capture, Non- } \\
\text { invasive DNA sampling, e.g. through hair } \\
\text { traps, scat collection, antler/skin collection }\end{array}$ \\
\hline & Genetic variability & $\begin{array}{l}\text { Invasive DNA sampling after capture, Non- } \\
\text { invasive DNA sampling }\end{array}$ \\
\hline
\end{tabular}

The list provides primarily some examples of frequently used survey methods and is not aimed at being complete

during the study due to changes in land use, or a positive trend in population size due to road mitigation may be observed but more years of measurement than planned seem to be needed to provide statistically significant results. Preferably, the monitoring plan includes an analysis of such risks and presents practical solutions on how to avoid them and what to do when they are unavoidable. For example, if our sampling scheme is based on ten replicates, we may select and sample at two more sites (i.e., for a total of 12), as a back-up for sites that may unexpectedly become unsuitable during the study.

The feasibility of a study can be easily increased using the protocol described in this paper, as at most steps there is choice on how to proceed (Fig. 1). Hence, when one or more resources are expected to be limiting, a different decision at one or more steps (e.g., choice of target species or measurement endpoint) may provide a practical solution. We do not recommend, however, leaving out essential components of an evaluation, such as the measurement of covariates, an often underestimated part of evaluation studies in 
terms of effort and budget, as this will considerably reduce the inferential strength of the study, limit the possibilities to compare study sites or extrapolate, and decrease the ability to explain the results. Hence, if choices have to be made, we recommend conducting one scientifically rigorous study that is more likely to contribute new knowledge than numerous poorly-designed studies.

\section{Added value of road mitigation evaluations}

Road mitigation measures have become integral components of major road construction projects in developed countries - and are becoming so in developing countries-where environmental impacts are likely to be large and unavoidable. Increasingly, mitigation attempts are also common as part of regional or national defragmentation strategies for existing road networks (e.g., Hlavac 2005; Holzgang et al. 2005; Böttcher et al. 2005; Grau 2005; Tillmann 2005; van der Grift 2005; van der Grift et al. 2008). These trends emphasize the need for proper evaluations of the effectiveness of road mitigation measures. Such evaluations produce considerable added value for policy makers and transportation planners because they are necessary to enhance the effectiveness of existing and future road mitigation projects. Demonstrable financial and environmental benefits will provide stronger justification for the construction of future mitigation measures. Thorough evaluation of road mitigation projects will answer two questions: What additions or changes in mitigation measures need to be made to improve effectiveness? And: What mitigation measures use the fewest resources? Hence, road mitigation evaluations will help us to provide cheaper but more effective ways of mitigating road effects on wildlife.

\section{Incorporating proper evaluations in road planning}

The evaluation of the effectiveness and efficiency of road mitigation is a unique collaboration between those who plan, design, construct and manage the road, and scientists who study the responses of flora and fauna to the road and mitigation measures. Achieving a productive partnership between these groups is a significant challenge that must be overcome to move mitigation from the realm of assumed best practices into good science.

Successful evaluation studies are likely to require collaboration between researchers and road planners commences at the very earliest stages of road planning. A proper evaluation is characterized by a BACI study design, which includes several years of measurements before the road mitigation takes place. This is in contrast to current practice where discussion about the evaluation of road mitigation works typically begins after the road mitigation has already been installed. A change in this practice can, in our opinion, be best accomplished if the preparation of a monitoring plan for the evaluation of planned road mitigation measures is made an inseparable part of the legal processes that must be followed during the road planning stage (e.g., similar to the EIA process). Practical experience (van der Grift, pers. obs.) has shown that even in a country like The Netherlands where road mitigation is high on the political agenda, there is little effort to incorporate studies that evaluate effectiveness until late in the planning and construction process, probably because there is no legal requirement for the early development of a monitoring plan. Education of road planners, or presentation of guidelines for road mitigation evaluation during road planning may be helpful, but are not likely to be as effective as statutory duties and associated regulations. 
Another important factor in the success of an evaluation study is that all necessary resources are secured beforehand. Currently, road mitigation construction and road mitigation evaluation are often organized and administered as two different projects. The result is that construction can easily proceed without evaluation and that the preparation of a proper monitoring plan and the provision of resources for evaluation studies do not occur simultaneously with the construction planning. A common outcome is that the road is built and road mitigation is in place, but there are insufficient resources allocated to fully evaluate road mitigation measures. We recommend that evaluation studies become an integral part of the road or road mitigation construction project. This will better ensure that such studies are budgeted in a timely manner, properly planned in relation to the planning of the construction, and better communicated with stakeholders.

Integration of evaluation studies with the construction project will not solve all problems. A major challenge is also the compartmentalization and project-based organization of most road projects and agencies. Responsibility for the funding, construction and management of roads and road mitigation may be split among international, national, state/ province and local governments. And within levels, responsibilities may be further subdivided, with different sections or departments working on different road projects. Consequently, there may be little co-ordination among projects, even when building nearidentical mitigation devices. As such, funding is usually associated with a particular project, and hence mitigation sites and appropriate controls are often restricted to those available on a project by project basis. There would be significant gains in efficiency and inferential strength if resources could be pooled - including funds and study sites — among projects to produce well-designed studies of road mitigation effectiveness as recommended by the guidelines in this paper.

Finally, one of the most powerful approaches used in science is that of the manipulative experiment. Depending on the specific question being addressed, this may include opening and closing wildlife crossing structures and measuring population density, mortality rate or gene flow. In the case of testing effectiveness of mitigation structures, it would be ideal to build, say, ten crossing structures, and periodically shut/open them so we can experimentally test what happens to local populations. However, there are many reasons (e.g., finances invested, risk to local populations, political support) why it may be difficult to periodically close the structures. Our paper has focused on detailing the parameters we believe need to be studied in order to evaluate road mitigation effectiveness. However, we also strongly suggest that road agencies consider the installation of mitigation measures in a truly experimental manner to maximize the insights gained about their influence on population dynamics.

\section{Concluding remarks}

A comprehensive evaluation of the extent to which mitigation programs reduce the risk of decline and extinction of local populations is essential to ensure that conservation funds are being allocated in the most cost-effective manner. However, only a handful of studies have studied the population-level effects of wildlife crossing structures (van der Ree et al. 2011). We point out three key areas requiring greater investment and political will to ensure that road mitigation effectiveness, and not just rate of use of crossing structures, is assessed.

First, road management and permitting agencies need to move beyond asking consultants or researchers to simply record use or measure rate of crossing by fauna, to insisting on evaluations of whether the crossing structure has mitigated the effect of the road on the 
wildlife population. Second, researchers need to be involved in the design of the evaluation programs from the earliest stages of the road or road mitigation project. The researchers need to inform the road agency of the essential components of good study design and the need for (1) before data, (2) appropriate mitigation and control sites, (3) sufficient site replication, and (4) appropriate spatial scale and time-frame for evaluation. Finally, the importance and benefits of road mitigation measures should be better communicated to all stakeholders. Only then can the support and cooperation, which is indispensable for studies that are characterized by long-term monitoring efforts, be achieved. Although the set of guidelines we have presented is ambitious, we are convinced that they are necessary to improve our understanding of the effectiveness of road mitigation measures.

Acknowledgments The initial workshop, held at castle Geulzicht in The Netherlands, and the work on the paper by the first author have been financed by the Dutch Ministry of Agriculture, Nature and Food Quality (Policy Support Research, BO-02-005 Spatial Quality National Ecological Network) and the Ministry of Transport and Public Works. Co-finances were received by the research program KennisBasis (Theme 1: Planning and Management of Green and Blue Space). Co-author van der Ree is supported by The Baker Foundation.

Open Access This article is distributed under the terms of the Creative Commons Attribution License which permits any use, distribution, and reproduction in any medium, provided the original author(s) and the source are credited.

\section{References}

Arens P, van der Sluis T, van't Westende WPC, Vosman B, Vos CC, Smulders MJM (2007) Genetic population differentiation and connectivity among fragmented moor frog (Rana arvalis) populations in The Netherlands. Landsc Ecol 22:1489-1500

Ascensão F, Mira A (2007) Factors affecting culvert use by vertebrates along two stretches of road in southern Portugal. Ecol Restor 22:57-66

Balkenhol N, Waits LP (2009) Molecular road ecology: exploring the potential of genetics for investigating transportation impacts on wildlife. Mol Ecol 18:4151-4164

Becker DM, Basting PB (2010) Reconstruction of US Highway 93: Collaboration between three governments. In: Beckmann JP, Clevenger AP, Huijser MP, Hilty JA (eds) Safe passages—highways, wildlife and habitat connectivity. Island Press, Washington, DC, pp 173-187

Benítez-López A, Alkemade R, Verweij PA (2010) The impact of roads and other infrastructure on mammal and bird populations: a meta-analysis. Biol Conserv 143:1307-1316

Björklund M, Arrendal J (2008) Demo-genetic analysis of a recovering population of otters in central Sweden. Anim Conserv 11:529-534

Borda-de-Agua L, Navarro L, Gavinhos C, Pereira HM (2010) Spatio-temporal impacts of roads on the persistence of populations: analytic and numerical approaches. Landsc Ecol 26(2):253-265

Böttcher M, Reck H, Hänel K, Winter A (2005) Habitat corridors for humans and nature in Germany. Gaia 14(2):163-166

Clevenger AP, Ford A (2010) Wildlife crossing structures, fencing, and other highways design considerations. In: Beckmann JP, Clevenger AP, Huijser MP, Hilty JA (eds) Safe passages—highways, wildlife and habitat connectivity. Island Press, Washington DC, pp 17-50

Clevenger AP, Sawaya MA (2010) Piloting a non-invasive genetic sampling method for evaluating population-level benefits of wildlife crossing structures. Ecol Soc 15(1):7. http://www.ecologyandsociety. org/vol15/iss1/art7/

Clevenger AP, Waltho N (2000) Factors influencing the effectiveness of wildlife underpasses in Banff National Park, Alberta, Canada. Conserv Biol 14:47-56

Clevenger AP, Waltho N (2003) Long-term, year-round monitoring of wildlife crossing structures and the importance of temporal and spatial variability in performance studies. In: Irwin CL, Garrett P, McDermott KP (eds) 2003 Proceedings of the International Conference on Ecology and Transportation. Center for Transportation and the Environment, North Carolina State University, Raleigh, pp 293-302 
Clevenger AP, Waltho N (2005) Performance indices to identify attributes of highway crossing structures facilitating movement of large mammals. Biol Conserv 121:453-464

Coffin AW (2007) From roadkill to road ecology: a review of the ecological effects of roads. J Transp Geogr 15:396-406

Corlatti L, Hackländer K, Frey-Roos F (2009) Ability of wildlife overpasses to provide connectivity and prevent genetic isolation. Conserv Biol 23(3):548-556

Dodd CK, Barichivich WJ, Smith LL (2004) Effectiveness of a barrier wall and culverts in reducing wildlife mortality on a heavily travelled highway in Florida. Biol Conserv 118:619-631

Doran GT (1981) There's a S.M.A.R.T. way to write management's goals and objectives. Manag Rev $70(11): 35$

Epps CW, McCullough DR (2005) Highways block gene flow and cause a rapid decline in genetic diversity of desert bighorn sheep. Ecol Lett 8:1029-1038

Evink GL (2002) Interaction between roadways and wildlife ecology. A synthesis of highway practice. National cooperative highway research program synthesis 305, Transportation Research Board, Washington, DC

Fahrig L, Rytwinski T (2009) Effects of roads on animal abundance: An empirical review and synthesis. Ecol Soc 14(1):21. http://www.ecologyandsociety.org/vol14/iss1/art21/

Ford AT, Clevenger AP, Rettie K (2010) The Banff Wildlife Crossings Project: An international publicprivate partnership. In: Beckmann JP, Clevenger AP, Huijser MP, Hilty JA (eds) Safe passageshighways, wildlife and habitat connectivity. Island Press, Washington, DC, pp 157-173

Forman RTT, Alexander LE (1998) Roads and their major ecological effects. Annu Rev Ecol Syst 29:207-231

Forman RTT, Deblinger RD (2000) The ecological road-effect zone of a Massachusetts (USA) suburban highway. Conserv Biol 14(1):36-46

Forman RTT, Sperling D, Bissonette JA, Clevenger AP, Cutshall CD, Dale VH, Fahrig L, France R, Goldman CR, Heanue K, Jones JA, Swanson FJ, Turrentine T, Winter TC (2003) Road ecology. Science and solutions. Island Press, Washington, DC

Foster ML, Humphrey SR (1995) Use of highway underpasses by Florida panthers and other wildlife. Wildl Soc Bull 23:95-100

Frankham R (1996) Relationship of genetic variation to population size in wildlife. Conserv Biol 10(6):1500-1508

Frankham R (2005) Genetics and extinction. Biol Conserv 126:131-140

Gerlach G, Musolf K (2000) Fragmentation of landscape as a cause for genetic subdivision in bank voles. Conserv Biol 14(4):1066-1074

Glista DJ, De Vault TL, DeWoody JA (2009) A review of mitigation measures for reducing wildlife mortality on roadways. Landsc Urban Plan 91:1-7

Grau S (2005) Large-scale plans for landscape defragmentation in Germany. Gaia 14(2):153-162

Grilo C, Bissonette JA, Santos-Reis M (2008) Response of carnivores to existing highway culverts and underpasses: implications for road planning and mitigation. Biodivers Conserv 17:1685-1699

Hels T, Buchwald E (2001) The effect of road kills on amphibian populations. Biol Conserv 99:331-340

Hlavac V (2005) Increasing permeability of the Czech road network for large mammals. Gaia 14(2): $175-177$

Holzgang O, Righetti A, Pfister HP (2005) Swiss wildlife corridors on paper, imagined and in the countryside. Gaia 14(2):148-151

Huijser MP, Bergers PJM (2000) The effect of roads and traffic on hedgehog (Erinaceus europeaus) populations. Biol Conserv 95:111-116

Huijser MP, McGowen PT (2010) Reducing wildlife-vehicle collisions. In: Beckmann JP, Clevenger AP, Huijser MP, Hilty JA (eds) Safe passages-highways, wildlife and habitat connectivity. Island Press, Washington, DC, pp 51-74

Hunt A, Dickens HJ, Whelan RJ (1987) Movement of mammals through tunnels under railway lines. Aust Zool 24:89-93

Iuell B, Bekker GJ, Cuperus R, Dufek J, Fry G, Hicks C, Hlaváč V, Keller V, Rosell C, Sangwine T, Trøsløv N, le Wandall Maire B (2003) Wildlife and traffic: a European handbook for identifying conflicts and designing solutions. KNNV Publishers, Utrecht

Jaeger JAG, Fahrig L (2004) Effects of road fencing on population persistence. Conserv Biol 18:1651-1657

Jaeger JAG, Bowman J, Brennan J, Fahrig L, Bert D, Bouchard J, Charbonneau N, Frank K, Gruber B, Tluk von Toschanowitz K (2005) Predicting when animal populations are at risk from roads: an interactive model of road avoidance behaviour. Ecol Model 185:329-348

Keller I, Largiader CR (2003) Recent habitat fragmentation caused by major roads leads to reduction of gene flow and loss of genetic variability in ground beetles. Proc R Soc Lond, Ser B, Biol Sci 270:417-423 
Klar N, Herrmann M, Kramer-Schadt S (2009) Effects and mitigation of road impacts on individual movement behaviour of wildcats. J Wildl Manag 73(5):631-638

Kociolek AV, Clevenger AP, St-Clair CC, Proppe DS (2011) Effects of road networks on bird populations. Conserv Biol 25(2):241-249

Kusiak L, Hamerslag D (2003) Together on the road to a mobile, safe and accessible Limburg. Rijkswaterstaat Limburg, Maastricht, The Netherlands [in Dutch]

Lacy R (1997) Importance of genetic variation to the viability of mammalian populations. J Mammal 78(2):320-335

Lehnert ME, Bissonette JA (1997) Effectiveness of highway crosswalk structures at reducing deer-vehicle collisions. Wildl Soc Bull 25:809-818

Mansergh IM, Scotts DJ (1989) Habitat continuity and social organisation of the mountain pygmy-possum restored by tunnel. J Wildl Manag 53:701-707

McDonald W, St-Clair CC (2004) Elements that promote highway crossing structure use by small mammals in Banff National Park. J Appl Ecol 41:82-93

Mumme RL, Schoech SJ, Woolfenden GE, Fitzpatrick JW (2000) Life and death in the fast lane: demographic consequences of road mortality in the Florida scrub-jay. Conserv Biol 14:501-512

National Transportation Enhancements Clearinghouse (2009) Transportation enhancements: summary of nationwide spending as of FY 2008. Federal highway administration and rails-to-trails conservancy, Washington, DC

Ng SJ, Dole JW, Sauvajot RM, Riley SPD, Valone TJ (2004) Use of highway undercrossings by wildlife in southern California. Biol Conserv 115:499-507

Reed DH, Frankham R (2003) Correlation between fitness and genetic diversity. Conserv Biol 17(1):230-237

Reed DH, Nicholas AC, Stratton GE (2007) Genetic quality of individuals impacts population dynamics. Anim Conserv 10:275-283

Riley SPD, Pollinger JP, Sauvajot RM (2006) A southern California freeway is a physical and social barrier to gene flow in carnivores. Mol Ecol 15:1733-1741

Rodriguez A, Crema G, Delibes M (1996) Use of non-wildlife passages across a high speed railway by terrestrial vertebrates. J Appl Ecol 33:1527-1540

Rodriguez A, Crema G, Delibes M (1997) Factors affecting crossing of red foxes and wildcats through nonwildlife passages across a high-speed railway. Ecography 20:287-294

Roedenbeck IA, Fahrig L, Findlay CS, Houlahan JE, Jaeger JAG, Klar N, Kramer-Schadt S, van der Grift EA (2007) The Rauischholzhausen agenda for road ecology. Ecol Soc 12(1):11. http://www.ecology andsociety.org/vol12/iss1/art11/

Seiler A (2003) The toll of the automobile: Wildlife and roads in Sweden. Dissertation, Swedish University of Agricultural Sciences, Uppsala

Spellerberg IF (2002) Ecological effects of roads. Science Publisher, Plymouth

Suter GW (1990) Endpoints for regional ecological assessments. Environ Manag 14:9-23

Tillmann JE (2005) Habitat fragmentation and ecological networks in Europe. Gaia 14(2):119-123

Trocmé M, Cahill S, de Vries JG, Farrall H, Folkeson L, Fry G, Hicks C, Peymen J (eds) (2003) COST 341: Habitat fragmentation due to transportation infrastructure: the European review. Office for Official Publications of the European Communities, Luxembourg

Trombulak SC, Frissell CA (2000) Review of ecological effects of roads on terrestrial and aquatic communities. Conserv Biol 14(1):18-30

van der Grift EA (2005) Defragmentation in the Netherlands: a success story? Gaia 14(2):144-147

van der Grift EA, Pouwels R (2006) Restoring habitat connectivity across transport corridors: Identifying high-priority locations for de-fragmentation with the use of an expert-based model. In: Davenport J, Davenport JL (eds) The ecology of transportation: managing mobility for the environment. Springer, Dordrecht, pp 205-231

van der Grift EA, Snep RPH, Verboom J (2002) How wildlife passageways at national highways affect population viability: potential study sites. Alterra, Wageningen [in Dutch]

van der Grift EA, Verboom J, Pouwels R (2003) Assessing the impact of roads on animal population viability. In: Irwin CL, Garrett P, McDermott KP (eds) 2003 Proceedings of the International Conference on Ecology and Transportation. Center for Transportation and the Environment, North Carolina State University, Raleigh, pp 173-181

van der Grift EA, Simeonova V, Biserkov V (2008) Restoring ecological networks across transport corridors in Bulgaria. Alterra, Wageningen

van der Grift EA, Dirksen J, Jansman HAH, Kuijpers H, Wegman RMA (2009a) Update of goals and target species of the national Long-term Defragmentation Program in the Netherlands. Alterra, Wageningen [in Dutch] 
van der Grift EA, Jansman HAH, Koelewijn HP, Schippers P, Verboom J (2009b) Effectiveness of wildlife passages in transport corridors. Guidelines for the set-up of a monitoring plan, Alterra

van der Ree R, van der Grift EA, Gulle N, Holland K, Mata C, Suarez F (2007) Overcoming the barrier effect of roads: how effective are mitigation strategies? An international review of the use and effectiveness of underpasses and overpasses designed to increase the permeability of roads for wildlife. In: Irwin CL, Nelson D, McDermott KP (eds) 2007 Proceedings of the International Conference on Ecology and Transportation. Center for Transportation and the Environment, North Carolina State University, Raleigh, pp 423-431

van der Ree R, McCarthy MA, Heinze D, Mansergh IM (2009) Wildlife tunnel enhances population viability. Ecol Soc 14(2):7. http://www.ecologyandsociety.org/vol14/iss2/art7/

van der Ree R, Jaeger JAG, van der Grift EA, Clevenger AP (2011) Effects of roads and traffic on wildlife populations and landscape function: Road ecology is moving toward larger scales. Ecol Soc 16(1):48. http://www.ecologyandsociety.org/vol16/iss 1/art48/

van Vuurde MR, van der Grift EA (2005) The effects of landscape attributes on the use of small wildlife underpasses by weasel (Mustela nivalis) and stoat (Mustela erminea). Lutra 48(2):91-108

van Wieren SE, Worm PB (2001) The use of a motorway wildlife overpass by large mammals. Neth J Zool 51:97-105

Vos CC, Antonisse-De Jong AG, Goedhart PW, Smulders MJM (2001) Genetic similarity as a measure for connectivity between fragmented populations of the moor frog (Rana arvalis). Hered 86:598-608

Yanes M, Velasco J, Suarez F (1995) Permeability of roads and railways to vertebrates: the importance of culverts. Biol Conserv 71:217-222 